\title{
A Research on the Cognitive and Behavioral Foundations of Strategic Management: 1995-2020
}

\author{
Mehmet BAĞIȘ1
}

\begin{abstract}
This study analyzes the theories and research topics which address the cognitive and behavioral foundations of strategic management. In the research, the citation analysis as a bibliometric technique and qualitative content analysis as a qualitative research method were used. In 1995-2007 and 2008-2020 periods, the biggest contribution was made by a behavioral theory of the firm and by social psychology/cognitive theories. When 1995-2007 and 2008-2020 periods above were evaluated together, it was deduced that the topics such as managerial cognition, cognitive schemata, sense-making, managerial human/social capital, strategic decision-making, entrepreneurship, managerial attention and emotions guided the way for research studies that conducted at individual level of analysis. The dynamic capabilities came to the forefront at organizational level of analysis whereas the competitive dynamic and behavioral strategy themes came forward in strategic phenomena. Again, when 1995-2007 and 2008-2020 periods are evaluated together, the effect of inter-organizational and contextual analysis levels between 1995-2007 is quite limited. However, between 2008-2020, social networks at the interorganizational level and the environment, institutions and market phenomena at the contextual level came to the fore.
\end{abstract}

Keywords: Strategic management, cognitive foundations, behavioral foundations, bibliometric analysis, qualitative content analysis.

JEL Classification: M1, M10, M19.

\section{Introduction}

Theoretical pursuits starting with the positioning school in the strategic management research (Porter, 1980; 1981) enabled the emergence of a large variety of approaches and micro views until present. Resource-based view (Barney, 1991; Wernerfelt, 1984; Peteraf, 1993), natural resource-based view (Hart, 1995), knowledge-based view (Grant, 1996), dynamic capabilities (Teece, Pisano \& Shuen, 1997), attention-based view (Ocasio, 1997), relational view (Dyer \& Singh, 1998; Gulati, 1999; Lavie, 2006), strategy as a practice (Whittington, 1996) and institution-based view (Peng, 2002; Peng et al., 2009) are among these views. Along with this development process in the field, studies on the micro foundations of strategic management gained momentum in the early 2000s (Bağış, 2020; Bağış, 2018; Felin \& Foss, 2005; Lippman \& Rumelt, 2003). Micro foundations placed the focus on the phenomena at the individual level which were missing since the strategic management research focused mainly on phenomena at industry and firm levels. These studies analyzed the implications of individual factors (Abell, Felin \& Foss, 2008) and interactions between individuals (Hodgson, 2012) on organizational results and performance. Together with these studies, the managerial and organizational phenomena related to the human cognition and behavior which were neglected while laying the intellectual foundations of strategic management field for more than a decade (Winter, 2012: 288) were incorporated into the strategic management research.

According to the psychology discipline, cognitive responses are accepted as the precursors of individual behavior (Goldstein, 2014). Based on this acknowledgment, it has been suggested that managers 'cognitive structures and functioning are influential in strategic management, both in the background of managers'

\footnotetext{
${ }^{1}$ Assistant Professor, Sakarya University of Applied Sciences, Faculty of Applied Sciences, International Trade and Finance Department, mehmetbagis@subu.edu.tr
} 
strategic choices and firm behavior. As a matter of fact, within the framework of these admission and claims, Powell et al., (2011) placed cognitive and social psychology on the basis of behavioral strategy and defined the concept as follows: "Behavioral strategy merges cognitive and social psychology with strategic management theory and practice. Behavioral strategy aims to bring realistic assumptions about human cognition, emotions, and social behavior to the strategic management of organizations and, thereby, to enrich strategy theory, empirical research, and real-world practice."

In the field of strategic management, managerial and organizational cognition is a field of study which analyzes how the members of organization model the reality and how such models interact with the behaviors (Walsh, 1995). The main phenomena which are covered by this field are the social construction, culture and cognition, the nature and role of mental models and representations, judgment and decision-making, attribution processes, individual differences, non-conscious forms of cognition (e.g. intuition), cognitive institutionalism, emotion, ideology, identity/ identification, image, reputation, sense-making/meaning-making, symbols and artifacts, categorization, knowledge creation and management, individual learning, organizational learning and memory, and communities of practice (Kaplan, 2011; AOM, 2021). However, the research studies in this field are not solely limited to the analysis of these phenomena. The field endeavors to understand and explain the individual, relational and collective cognition in the organizations.

Approximately three decades ago, Mintzberg (1990: 145) made the following assessment on the cognitive school of strategic management: "This school is characterized more with its potential than its contribution."In this framework, the first attempts for the creation of the field were launched with the special issues of Journal of Management Studies published in July 1989 and May 1992 and Organization Science published in August 1994. This literature which developed until the mid1990s was reviewed for the first time by Walsh (1995). Walsh (1995) identified the research topics which guided the studies by categorizing the cognitive studies at different levels of analysis as individual, group, organization and industry. The study by Walsh (1995) which served as a turning point offered the careful review of practices of knowledge structures in strategic management and organizational theory. Following this study which acted as a pioneer in management scien- ces, different studies evaluated the research studies on the cognitive foundations of strategic management. In this respect, Kaplan (2011) analyzed the effect of the study by Porac, Thomas and Baden-Fuller (1989) on the field of strategic management and sought the traces of research studies performed in the field in the period of 1989-2009. Kaplan (2011) reviewed the key words of a total of 226 articles which were related to cognition and had citations from Porac et al., (1989). This review by Kaplan (2011) did not present the dominant research topics on the cognition and their patterns of transformation and development across time. Besides, Kaplan (2011) did not fully explain the relationship of cognition phenomenon in strategic management with the phenomena at different levels of analysis.

Narayanan, Zane and Kemmerer (2011) that analyzed the cognitive perspective in the field of strategic management performed a review on the literature of the period of 1993-2007. The research put forward an integrative framework on strategic cognition literature by defining the three elements of strategic cognition structure (organizational identity, strategy frames and organizational routines) and four processes (strategy formulation, strategy implementation, strategic transformation and organizational learning). Even if Narayanan et al., (2011) produced a categorization in relation to the theoretical and empirical research studies, they failed to offer a detailed explanation related to the theories which contributed to the cognitive foundations of strategic management. Moreover, as this study analyzed the period until 2007, information on the transformation which was experienced until 2020 by the cognitive foundations of strategic management is still not available.

As is to be viewed, there are two studies which analyzed the cognitive foundations of strategic management. Considering the shortcomings of previous studies, this current study seeks answers to the following research questions: i) Which theories contributed to the transformation in the cognitive foundations of strategic management in the period of 1995-2020? ii) What type of a transformation did the research topics on the cognitive foundations of strategic management have in the same time period? Based on these two research questions, this study aims to make research proposals that will contribute to the development of the strategic management field by revealing the theories and research topics that guide the cognitive and behavioral foundations of strategic management. In this context, the research method 
used in this study is presented in the next section. The third part consists of findings, and in the fourth part, the research findings are discussed. Finally, the study is completed with the conclusion section.

\section{Methodology}

In the research, the citation analysis as a bibliometric technique and the qualitative content analysis as a qualitative research method were used. Firstly, by utilizing the Web of Science data search criteria, the research data were accessed from the Social Science Citation Index (SSCI) (Bağış et al., 2019; Bağış, 2020; Acedo, Barroso \& Galan, 2006; Ramos-Rodríguez \& Ruíz-Navarro, 2004; Çark, 2020). This database was preferred as it was the database which was the most commonly used by scientists (Zupic \& Čater, 2014). Using solely this database created a limitation for this research by preventing other articles in other databases such as Ulakbim, Scopus, Proquest and Ebsco from being included into this research. Another issue which created a limitation for this study is that the articles which were composed in different languages such as Turkish, Russian, Chinese, German, Japanese and Hindi could not be included into the research. Therefore, the research remained limited solely to the review of journals published in North America and studies sent to these journals from different countries.

In data search process, the phrase, 'cognition and cognitive', was used in the topic category of Web of Science. As the date range, the period of 1995-2020 was selected. In the selection of this date range, the evaluation made by Walsh (1995) on the managerial and organizational cognition literature served as the reference point. This study evaluated the cognitive studies which were performed until 1995 in the field of management sciences in general and in the field of strategy in particular. Following the search performed with the phrase, 'cognition and cognitive', the publications in the field of management and business were filtered through the Web of Science search categories. Afterwards, only the article was selected as the type of document. Analyzing only the articles is based on certain premises: i) In scientific research, the articles are verified sources of knowledge (Fernandez-Alles \& Ramos-Rodríguez, 2009). ii) As the articles pass through a process under the supervision of referees, no problem is observed in terms of quality in general (Gürbüz \& Şahin, 2014). iii) In scientific research, the articles are more suitable in terms of production quantity and quality. Subsequently, the journals which were well-suited to our research were selected from the source title in the data filtering category of Web of Science. The journals which were selected for this current research were limited to Strategic Management Journal, Advances in Strategic Management Research Annual, Strategic Entrepreneurship Journal, Journal of Management, Journal of Management Studies, Academy of Management Journal and Organization Science. These journals were selected as they had significant academic impact on the field of strategic management. Along with the selection process, 339 articles were obtained for the research. At this stage, the publications were enumerated in descending order from these with the highest number of citations to those with the lowest number of citations by using the citation analysis from among bibliometric techniques (Zupic \& Čater, 2014). In enumerating the publications, 'times cited' property of Web of Science was employed. This process offered the opportunity to identify the studies which had the highest number of citations and were the most effective in the field. Thus, the literature to be reviewed was structured by objectively retrieving the studies to be included to the qualitative content analysis from the database.

A total of 339 articles were analyzed by means of qualitative content analysis. Firstly, the key words of each article were separately noted down. In the articles without key words, the main themes were identified by examining the abstract, introduction and methodology parts of articles. After these steps, the first stage of data encoding was started. All coding processes were done manually and no analysis program was used. According to the initial review of the data, the articles were coded as relevant or irrelevant to strategic management and cognitive studies. With this stage of data coding, it was determined that 79 articles were not related to strategic management and cognitive issues. These articles are generally about management science, but in particular, organizational behavior, organizational theory and human resource management. In other words, they are not articles directly related to strategic management and cognitive foundations. Therefore, since the main focus of the study was to reach the cognitive and behavioral foundations of strategic management, it was thought that these articles would negatively affect the research results. Therefore, it was decided to exclude 79 articles from the analysis process. It was ascertained that the remaining 260 articles were relevant to the field of strategic management and these studies were guided by the cognitive themes. The breakdown of articles by year and journal is indicated in Table 1. 
Table 1: Journals and the Number of Articles Used in the Study

\begin{tabular}{lccc}
\hline Journal & $\mathbf{1 9 9 5 - 2 0 0 7}$ & $\mathbf{2 0 0 8 - 2 0 2 0}$ & Total \\
\hline Strategic Management Journal & 26 & 49 & 75 \\
\hline Strategic Entrepreneurship Journal & 3 & 22 & 25 \\
\hline Advances in Strategic Management Research Annual & 3 & 15 & 18 \\
\hline Journal of Management & 3 & 27 & 30 \\
\hline Journal of Management Studies & 12 & 18 & 30 \\
\hline Academy of Management Journal & 4 & 15 & 19 \\
\hline Organization Science & Total & $\mathbf{7 4}$ & 40 \\
\hline
\end{tabular}

The table was created by the author of this article.

In the second phase of the research, a data coding process in relation to the theories which contributed to the cognitive foundations of strategic management was put in place. Upon being identified through the reading method, the theoretical frameworks which were employed by each article were grouped on the basis of economics, sociology and psychology disciplines. Alongside the grouping process, it was found that 6 theories from economics, 10 theories from sociology and 19 theories from psychology made contributions to the cognitive foundations of strategic management. Table 2 displayed the categorization of theories by discipline as well as the researchers who used these theories. Data were presented as time periods of 12 years, namely, 1995-2007 (the first period) and 2008-2020 (the second period). In the division of time periods in this manner, the departure point was the acknowledgment that a transformation in a field would take place in a time period of 10 years (Üsdiken \&Wasti, 2002).

In the third phase of data coding, the research topics were analyzed. In this phase, the key words and research themes obtained from the articles were utilized. Later, the key words and designated research themes were coded from sub-categories to categories. Subsequently, a coding process took place also from the created categories to main categories (Bowen, 2009; Miles \& Huberman, 1994). Hence, the data coding was performed through an inductive analysis. Through the findings retrieved from the main categories, a designation as the individual, organizational, interorganizational and contextual factors was specified as the levels of analysis (Grégoire, Corbett \& McMullen, 2011; Walsh, 1995). In this selection, the aim was to be able to see the relationships between the levels of analysis in the research studies which guided the way for cognitive foundations of strategic management. As per the results of analysis, the findings obtained for the period of 1995-2007 were exhibited in Table 3 whilst the findings obtained for the period of 2008-2020 were indicated in Table 4. The next part continued with the presentation of research findings.

\section{Findings}

\subsection{Effects of Theories}

\subsubsection{Economics-Based Theories}

Which theories contributed to the cognitive foundations of strategic management was presented in Table 2. The findings demonstrate that the theories from economics, sociology and psychology disciplines made contributions to the cognitive foundations in both time periods. According to the analysis, it was determined that 6 economic theories contributed to the cognitive foundations of strategic management: A behavioral theory of the firm, evolutionary theory of economic change, theory of the growth of the firm, agency theory, Austrian school of economics, game theory and behavioral game theory. When the economic theories in Table 2 are examined on the basis of the number of publications, it is seen that the most contribution and the theory studied in the periods of 1995-2007 and 2008-2020 is the behavioral theory of the firm (Cyert \& March, 1963), which was developed by the efforts of the Carnegie School. 
Table 2: Theories Contributing to the Cognitive Foundations of Strategic Management in the Periods of 19952007 and $2008-2020$

\begin{tabular}{|c|c|c|c|}
\hline & Theories & 1995-2007 & 2008-2020 \\
\hline \multirow{6}{*}{ 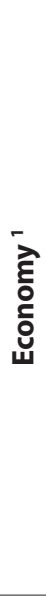 } & $\begin{array}{l}\text { A behavioral theory of } \\
\text { the firm }\end{array}$ & $\begin{array}{l}\text { Adner and Helfat, 2003; } \\
\text { Gavetti, 2005; Gavetti et al., } \\
\text { 2007; Gavetti and Rivkin, } \\
\text { 2007; Winter et al., } 2007\end{array}$ & $\begin{array}{l}\text { Rerup, 2009; Felin and Zenger, 2009; Pollock et al., 2009; Ocasio, } \\
\text { 2011; Powell et al., 2011; Hodgkinson and Healey, 2011; Felin } \\
\text { et al., 2012; Gavetti, 2012; Winter, 2012; Petkova et al., 2014; } \\
\text { Zbaracki and Bergen, 2015; Csasza and Levinthal, 2016; Joseph } \\
\text { et al., 2016; Powell, 2018; Bromiley et al., } 2019\end{array}$ \\
\hline & $\begin{array}{l}\text { Evolutionary theory of } \\
\text { economic change }\end{array}$ & $\begin{array}{l}\text { Helfat, 2000; Gavetti, 2005; } \\
\text { Gavetti and Rivkin, } 2007\end{array}$ & Gavetti, 2012 \\
\hline & $\begin{array}{l}\text { The theory of the } \\
\text { growth of the firm }\end{array}$ & & Gruber et al., 2012; Joseph and Wilson, 2018 \\
\hline & Agency theory & $\begin{array}{l}\text { Castanias and Helfat, 2000; } \\
\text { Mahnke et al., } 2007\end{array}$ & \\
\hline & $\begin{array}{l}\text { Austrian school of } \\
\text { economics }\end{array}$ & & Barreto, 2012 \\
\hline & $\begin{array}{l}\text { Game theory, } \\
\text { behavioral game theory }\end{array}$ & & $\begin{array}{l}\text { Powell et al., 2011; Levine et al., 2017; Menon, 2018; Powell, } \\
\text { 2018; Du et al., } 2019\end{array}$ \\
\hline \multirow{10}{*}{ 층 } & Institutional theory & $\begin{array}{l}\text { Anand and Peterson, 2000; } \\
\text { Karamanos, } 2003\end{array}$ & $\begin{array}{l}\text { Julian et al., 2008; Pollock et al., 2009; Ng et al., 2009; Dacin et al., } \\
\text { 2011; Kahl et al., 2012; Fonti et al., 2017; Vedula et al., } 2019\end{array}$ \\
\hline & $\begin{array}{l}\text { Resource dependence } \\
\text { theory }\end{array}$ & & Julian et al., 2008; Pollock et al., 2009 \\
\hline & Social network theory & $\begin{array}{l}\text { Dacin et al., 1999; } \\
\text { Karamanos, } 2003\end{array}$ & $\begin{array}{l}\text { Dacin et al., 2011; Brands and Kilduff, 2014; Bridwell-Mitchell } \\
\text { and Lant, 2014; Tasselli et al., 2015; Meuser et al., } 2016\end{array}$ \\
\hline & Contingency approach & Miller and Chen, 1996 & Miller and Lin, 2015 \\
\hline & Structuration theory & & Pryor et al., 2016 \\
\hline & $\begin{array}{l}\text { Cultural consensus } \\
\text { theory }\end{array}$ & & Keller and Loewenstein, 2011 \\
\hline & Organizational ecology & & Schwarz, 2012 \\
\hline & $\begin{array}{l}\text { Social contagion } \\
\text { theories }\end{array}$ & & Fonti et al., 2017 \\
\hline & Social capital theory & Ibarra et al., 2005 & Brown et al., 2017 \\
\hline & $\begin{array}{l}\text { Interaction ritual chain } \\
\text { theory }\end{array}$ & & Goss and Sadler-Smith, 2018 \\
\hline \multirow[t]{4}{*}{ 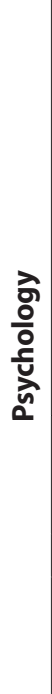 } & $\begin{array}{l}\text { Social psychology, } \\
\text { cognition theories }\end{array}$ & $\begin{array}{l}\text { Knight et al., 1999; } \\
\text { Hodgkinson et al., 1999; } \\
\text { Lant and Phelps, 1999; } \\
\text { Mitchell et al., 2000; Seijts } \\
\text { et al., 2004; Haleblian and } \\
\text { Rajagopalan, } 2005\end{array}$ & $\begin{array}{l}\text { Hmieleski and Baron, 2008a; Julian et al., 2008; Ringberg and } \\
\text { Reihlen, 2008; Mitchell et al., 2008; Shalley and Smith, 2008; } \\
\text { Pollock et al., 2009; Baum and Bird, 2010; Powell et al., 2011; } \\
\text { Hodgkinson and Healey, 2011; Powell, 2011; Bagozzi et al., 2013; } \\
\text { Petkova et al., 2014; Wu et al., 2014; Laureiro-Martinez, 2014; } \\
\text { Helfat and Peteraf, 2015; Laureiro-Martinez et al., 2015; Martins } \\
\text { et al., 2015; Furnari, 2015; Waldron et al., 2016; Uygur and Kim, } \\
\text { 2016; Glaser et al., 2016; Westphal and Shani, 2016; Heavey } \\
\text { and Şimşek, 2017; Brown et al., 2017; Salvato and Vassolo, 2018; } \\
\text { Samba et al., 2018; Liang et al., 2018; Knoben et al., 2018; Rickley, } \\
2019\end{array}$ \\
\hline & $\begin{array}{l}\text { Organizational learning } \\
\text { theory }\end{array}$ & $\begin{array}{l}\text { Thomas et al., 2001; Akbar, } \\
\text { 2003; Karamanos, } 2003\end{array}$ & $\begin{array}{l}\text { Rerup, 2009; Baron and Henry, 2010; Bingham and Eisenhardt, } \\
\text { 2011; Gavetti, 2012; Kostopoulos et al., 2013; Laureiro-Martinez, } \\
\text { 2014; Bingham and Kahl, } 2014\end{array}$ \\
\hline & Situated learning theory & Lant and Phelps, 1999 & \\
\hline & $\begin{array}{l}\text { Behavioral decision } \\
\text { theory }\end{array}$ & $\begin{array}{l}\text { Ocasio, 1997; Hodgkinson } \\
\text { et al., 1999; Hodgkinson et } \\
\text { al., } 2002\end{array}$ & $\begin{array}{l}\text { Powell et al., 2011; Hodgkinson and Healey, 2011; Garbuio et al., } \\
\text { 2011; Helfat and Peteraf, 2015; Powell, } 2018\end{array}$ \\
\hline
\end{tabular}

'Although it is difficult to make clear distinctions between the disciplines of economics, sociology and psychology in classifying the theories obtained from the analysis according to the main disciplines, the classifications made by previous studies on this subject have been used. For detailed information see: Barca (2017); Bromiley (2009); Bağış (2020); Bağış et al., (2019). Previous studies show that the greatest contribution to strategic management comes from the disciplines of economics, sociology, and psychology (Barca, 2017: 78; Bromiley, 2009; Bağış and Hızıroğlu, 2018; Jemison, 1981; Williamson, 1999). For this reason, a classification of the theories obtained as a result of the analyzes in this study is made according to the disciplines of economics, sociology and psychology. 


\begin{tabular}{|c|c|c|c|}
\hline & Theories & $1995-2007$ & 2008-2020 \\
\hline \multirow{15}{*}{ 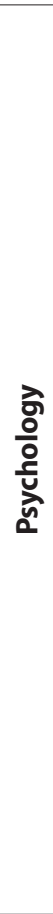 } & Prospect theory & $\begin{array}{l}\text { Das and Teng, 2001; Wright } \\
\text { and Goodwin, } 2002\end{array}$ & Powell et al., 2011; Malhotra et al., 2018 \\
\hline & Goal-setting theory & Seijts et al., 2004 & \\
\hline & Regulatory focus theory & & Hmieleski and Baron, 2008b; Weber, 2017 \\
\hline & $\begin{array}{l}\text { Transactive memory } \\
\text { theory }\end{array}$ & $\begin{array}{l}\text { Brandon and Hollingshead, } \\
2004\end{array}$ & $\begin{array}{l}\text { Jarvenpaa and Majchrzak, 2008; Mohammed et al., 2010; Mell et } \\
\text { al., 2014; Heavey and Şimşek, } 2017\end{array}$ \\
\hline & $\begin{array}{l}\text { Information processing } \\
\text { theory }\end{array}$ & $\begin{array}{l}\text { Mitchell et al., 2000; } \\
\text { Anand and Peterson, 2000; } \\
\text { Kuvaas, } 2002\end{array}$ & $\begin{array}{l}\text { Felin and Zenger, 2009; Marcel et al., 2011; Kiss and Barr, 2015; } \\
\text { Goswami et al., 2018; Samba et al., } 2018\end{array}$ \\
\hline & Social identity theory & & $\begin{array}{l}\text { Powell et al., 2011; Hodgkinson and Healey, 2011; Pandza, 2011; } \\
\text { Kammerlander et al., 2018; Bednar et al., } 2020\end{array}$ \\
\hline & Sense-making theory & & $\begin{array}{l}\text { Nadkarni et al., 2011; Kaplan and Orlikowski, 2013; Pryor et al., } \\
2016\end{array}$ \\
\hline & Attitude theory & & Rafferty et al., 2013 \\
\hline & Theory of mind & & Bagozzi et al., 2013; Stea et al., 2015 \\
\hline & Personal construct theory & & Wright et al., 2013 \\
\hline & Gender role theory & & Brands and Kilduff, 2014 \\
\hline & Attribution theory & $\begin{array}{l}\text { Haleblian and Rajagopalan, } \\
2006\end{array}$ & Chen et al., 2015 \\
\hline & Gestalt theory & & Loock and Hacklin, 2015 \\
\hline & Role identity theory & & Mathias and Williams, 2017 \\
\hline & Dual process theory & Wagner and Gooding, 1997 & Knoben et al., 2018 \\
\hline
\end{tabular}

The table was created by the author of this article.

This theory is a process-based firm theory which offers explanations on the businesses and ways of economic decision-making. The studies which made use of this theory analyzed the effect of managerial cognition on explaining the dynamic managerial capabilities (Adner \& Helfat, 2003), the effect of cognitive phenomena on the development of capabilities (Gavetti, 2005) and managers' perspectives on how to develop strategies (Gavetti \& Rivkin, 2007). These research studies which were performed in the period of 1995-2007 transferred the concepts of satisficing, aspiration level, problemistic search, bounded rationality and routines from behavioral theory of the firm to the micro foundations of strategic management in general and to the behavioral and cognitive foundations of strategic management in particular (Bromiley, 2009).

The concept of satisficing refers to the situation in which the individuals select the first alternative option which satisfies (March, 1994). The aspiration level affects this selection by the individuals. The aspiration level refers to a state which represents a target. When human beings reach targets above their aspiration levels, they feel successful. However, if they fail to reach their targets, they feel unsuccessful. The concept of problemistic search is a condition which is fulfilled by the individuals having the need to access full information (Bromiley, 2009). The failures to obtain satisfying results will tri- gger the search process. When a specific alternative is expected to be satisfying, the search process is stopped (Cyert \& March, 1963). Another concept, the bounded rationality, refers to the limitations in individuals capabilities of perceiving, information-processing and information-storing (Simon, 1947). Lastly, the routines refer to the behavior with which the organization will be capable of solving the problem without conducting any search when any problem or warning is confronted by the organization (Cyert \& March, 1963: 101).

In the period of 2008-2020, behavioral theory of the firm was used in the pursuit of psychological foundations for strategic management (Hodgkinson \& Healey, 2011), in the development of the attention-based view of strategic management (Ocasio, 2011) and in the efforts to create the field of behavioral strategy (Powell et al., 2011). Certain studies performed in this period made use of behavioral theory of the firm in order to indicate that the managerial (individual) cognition contributed to the differences in firm behavior. These studies opened the black boxes of firm capabilities (Felin et al., 2012) and the phenomenon of the entrepreneurial belief formation (Felin \& Zenger, 2009). Thus, the contributions of cognitive phenomena to the micro foundations of strategic management were researched. These studies which were performed in the second period employed 
the concepts which were transferred by the studies of the first period from behavioral theory of the firm

\subsubsection{Sociology-Based Theories}

As can be seen from Table 2, 10 theories based on sociology were determined as a result of the analysis. The theories of sociology which contributed to the cognitive foundations of strategic management are the following: Institutional theory, resource dependence theory, social network theory, contingency approach, structuration theory, cultural consensus theory, organizational ecology, social contagion theory, social capital theory and interaction ritual chain theory. While six theories of economics contributed to the cognitive foundations, ten theories of sociology made contributions to the cognitive foundations of strategic management. However, it is discerned that no theory of sociology had a dominant effect on cognitive foundations of strategic management as in the case of behavioral theory of the firm of economics

\subsubsection{Psychology-Based Theories}

Psychology is the discipline which made bigger contributions to the cognitive foundations of strategic management than economics and sociology did. The following 19 theories of psychology have effects on cognitive foundations of strategic management: Social psychology-cognition theories, organizational learning theory, situated learning theory, behavioral decision theory, prospect theory, goal-setting theory, regulatory focus theory, transactive memory theory, information processing theory, social identity theory, sense-making theory, attitude theory, theory of mind, personal construct theory, gender role theory, attribution theory, gestalt theory, role identity theory and dual process theory. When the findings in Table 2 are examined on the basis of the number of publications, it is seen that the social cognitive theory from the psychology discipline is used predominantly in studies on the cognitive foundations of strategic management.

Social cognitive theory assumes that the psychosocial functioning comes into play through a trilateral interaction between individual, environment and behavior. This theory offers phenomena related to human beings' self-regulatory capabilities. The application areas of the theory in organizational practices were addressed under the studies performed prior to 1995 (Bandura, 1988, 1989; Wood \& Bandura, 1989). However, in the following years, concepts of the theory were used in the field of strategic management. In the period of 19952007 , the studies carried out in the field of strategic management benefited from the self-efficacy concept of the theory (Haleblian \& Rajagopalan, 2005; Seijts et al., 2004). Self-efficacy is defined as individual's belief in taking control of the incidents affecting his/her life and of works performed by him/her (Bandura, 1991).

In the period of 2008-2020, social cognitive theory was employed for analyzing the relationship of cognitive foundations with phenomena such as the effects of entrepreneurial self-efficacy on firm performance, firm growth and entrepreneurial judgment (Baum \& Bird, 2010; Hmieleski \& Baron, 2008; Uygur \& Kim, 2016) and the role of learning by observing and effective experience in the team creativity (Shalley \& Perry-Smith, 2008). Certain studies benefited from 'Social Cognitive Theory' in examining the psychological foundations of research studies performed by the pluralist school which was among the three schools of strategy (Powell et al., 2011). Hodgkinson and Healey (2011), the researchers who studied the psychological foundations of dynamic capabilities, asserted that social cognitive theory could be used for producing a new wave of research in behavioral strategy. Hodgkinson and Healey (2011) recommended that the metacognition, emotion management and self-regulation or self-efficacy should be used in the micro foundations of dynamic capabilities.

Both in the first period and the second period, it is discerned that behavioral theory of the firm of economics and social cognitive theory of psychology guided the cognitive and behavioral foundations of strategic management. This situation proves that individuals' cognitive and mental activities should be evaluated together with their behaviors. Moreover, the domination of the field by two theories, one from economics and another from psychology, demonstrates that the research based on behavioral economics could be conducted in the field. Following the explanations which were made up to present on theories guiding the cognitive foundations of strategic management, data on the research topics which guided the cognitive foundations were presented in the next part

\subsection{Effects of Research Topics}

\subsubsection{Effects of Research Topics in the Period 1995-2007}

Research topics guiding the cognitive foundations of strategic management were grouped under four different levels of analysis/main categories, namely, individual, organizational, interorganizational and contextual levels. The findings on the period of 1995- 
2007 were indicated in Table 3. As per the analysis of data, it is discerned that the categories of cognition, top management/entrepreneur, sensing, seizing/decision-making and other individual variables were under the phenomena at the individual level of analysis. When the dominant research themes under each category are examined, the domination of cognitive foundations of strategic management by certain themes attracts the attention. It is discerned that managerial and organizational cognition, cognitive schemas, cognitive bias and strategic cognition topics are under the category of cognition. The managerial and organizational cognition analyzes the organizational implications of mental models and managerial beliefs which affect managers' decision-making processes (Walsh, 1995). Cognitive schemas (also called as dominant logics, belief structures, strategic schemas, cognitive maps or strategy frames) are a key component of data processing (Kiss \& Barr, 2015). Cognitive schemas are cognitive structures which represent the organized knowledge about a specific situation related to the firm and its environment. These structures are mental constructs which affect the knowledge which the human beings use, discern, think over and recall for arranging their knowledge about social world in the framework of themes or topics (Aronson, Wilson \& Akert, 2005). These schemas are employed in the strategic decision-making process by the top-level management team of the firm (Kiss \& Barr, 2015).

Another category designated under the main category of individual is the category of top management/entrepreneur. Dominant research topics which come forth under the category of top management/ entrepreneur are managerial human and social capital. While the managerial human capital refers to the skills acquired by managers from experience, education and learning, managerial social capital is defined as a skill which the managers develop with their social relationships and networks (Adner \& Helfat, 2003). Other dominant research themes under the category of top management/entrepreneur are entrepreneurship, entrepreneurs, entrepreneurial risk taking/aversion and entrepreneurial uncertainty. Of the research themes, the most noteworthy theme is the entrepreneurial risk taking/aversion. Risk taking refers to the institutional strategic moves which create changes in returns, embrace the engagement with the unknown and are likely to give rise to institutional destruction (Das \& Teng, 2001) whereas the risk aversion pertains to the opposite. The concept was transferred from the prospect theory of Kahneman and Tversky (1979) to the cognitive foundations of strategic management. Entrepreneurial uncertainty denotes the case in which the decision-maker is unable to know all likely outcomes of his/her entrepreneurial efforts (Shepherd, McMullen \& Jennings, 2007).

Themes designated under the category of sensing are sense-making, managerial perception, interpretation and non-conscious forms of cognition (e.g. intuition, heuristics). Sense-making is defined as the process of creation of reality by individuals collectively in their daily lives in organizations, making sense of the experiences and establishing an order through sense-making (Weick, 1995). Managerial perception is defined as the mental activities or processes which organize and interpret the knowledge produced by the properties of objects or incidents outside the firm (Helfat \& Peteraf, 2015). While the intuition which is one of the concepts in the non-conscious forms of cognition refers to our skill in knowing or understanding an issue without reasoning or substantiation, heuristics is defined as a problem-solving method which uses shortcuts for producing sufficiently good solutions in a limited time span (Kahneman, 2011).

Research topics under the category of seizing/decision-making are strategic decision-making, strategic choice, automatic and controlled information processing, bounded rationality and analogical reasoning. Under the category of other individual variables, two research themes were found. These themes are the concepts of emotions and tacit knowledge (Polanyi, 1967). Decision-making is the case in which the managers select one of the different options whilst the strategic choice refers to strategic decisions which shape the future of firms (Takemura, 2014: 3). Information processing is the process in which incoming information provided by the external environment is evaluated through attention, perception and a series of processing systems in short-term memory (De Wit \& Meyer, 2010). These processing systems transform or change the information through systematic ways. Automatic thinking or information processing is the recognition or comprehension system which is set in motion in an uncontrolled, effortless, associative, fast, unconscious and skillful manner (Kahneman, 2011). Conscious thinking or information processing is a thinking system which functions in a controlled, arduous, deductive, slow and conscious manner and in accordance with rules (Thaler \& Sunstein, 2009). 
Table 3: Research Topics in the Period of 1995-2007

\begin{tabular}{|c|c|c|c|c|c|}
\hline \multicolumn{2}{|r|}{ Individual Level } & \multirow{2}{*}{$\frac{\mathbf{f}^{2}}{43}$} & \multicolumn{2}{|r|}{ Organizational Level } & $\mathbf{f}$ \\
\hline \multirow{9}{*}{ 高 } & Managerial and Organizational Cognition & & \multirow{9}{*}{ 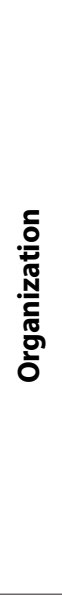 } & $\begin{array}{l}\text { Dynamic capabilities/resources/exploration and } \\
\text { exploitation/innovation }\end{array}$ & 16 \\
\hline & $\begin{array}{l}\text { Cognitive/mental/knowledge/belief schemas, } \\
\text { maps, frames, lenses, representations, structures }\end{array}$ & 30 & & Organizational learning & 8 \\
\hline & Cognitive bias & 6 & & Organizational performance & 5 \\
\hline & Strategic cognition & 4 & & Organizational change & 4 \\
\hline & Cognitive processes & 3 & & Organizational identity & 4 \\
\hline & Cognitive inertia & 2 & & Organizational evolution & 3 \\
\hline & Creative human cognition & 2 & & Organizational contexts & 5 \\
\hline & $\begin{array}{l}\text { Other cognitive factors (social cognition, } \\
\text { distributed, shared, situated cognition, } \\
\text { withdrawal cognitions, filters, diversity, } \\
\text { resources, paradoxical cognition, cognitive } \\
\text { illusion) }\end{array}$ & 11 & & $\begin{array}{l}\text { Other organizational factors (embeddedness, } \\
\text { schemas, information processing, attention, } \\
\text { search, process, decision-making, reputation, } \\
\text { incentives, complexity) }\end{array}$ & 11 \\
\hline & $\begin{array}{rc}\text { TOTAL } \\
\end{array}$ & 101 & & TOTAL & 56 \\
\hline \multirow{7}{*}{ 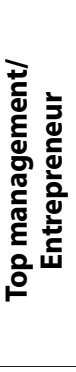 } & Managerial human/social capital & 4 & \multicolumn{3}{|c|}{ Organizational Level } \\
\hline & Top management teams & 3 & \multirow{5}{*}{ 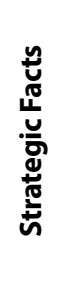 } & Competitive dynamics & 10 \\
\hline & Entrepreneurship & 7 & & Strategic groups & 7 \\
\hline & Entrepreneurial risk taking/aversion & 3 & & Strategic change & 7 \\
\hline & Entrepreneurs & 2 & & $\begin{array}{l}\text { Other strategic factors (strategic search, } \\
\text { consensus, formulation, formation, learning, risk } \\
\text { behavior, management) }\end{array}$ & 8 \\
\hline & Top managers' attributions & 6 & & \begin{tabular}{rc|} 
TOTAL \\
\end{tabular} & 32 \\
\hline & TOTAL & 25 & \multirow{4}{*}{ 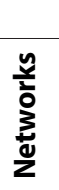 } & Interorganizational Level & \\
\hline \multirow{5}{*}{ 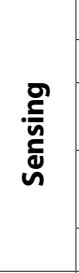 } & Sense-making & 8 & & Social networks & 2 \\
\hline & Managerial perception & 6 & & Joint ventures & 1 \\
\hline & Interpretation & 4 & & TOTAL & 3 \\
\hline & $\begin{array}{l}\text { Non-conscious forms of cognition (e.g. } \\
\text { Intuition, Heuristics) }\end{array}$ & 3 & \multicolumn{3}{|c|}{ Contextual Level } \\
\hline & $\begin{array}{rr}\text { TOTAL } \\
\end{array}$ & 21 & \multirow{6}{*}{ 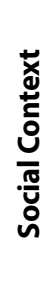 } & Structural mechanisms & 2 \\
\hline \multirow{6}{*}{ 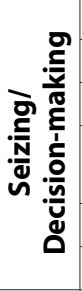 } & Strategic decision-making & 11 & & Environmental context & 2 \\
\hline & Strategic choice & 4 & & Informational context & 1 \\
\hline & Analogical reasoning/problem solving & 4 & & Thinking in context & 1 \\
\hline & $\begin{array}{l}\text { Automatic and controlled information } \\
\text { processing }\end{array}$ & 3 & & Leadership context & 1 \\
\hline & Bounded rationality & 2 & & TOTAL & 7 \\
\hline & TOTAL & 24 & \multirow{3}{*}{ 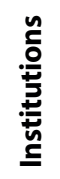 } & National and international institutions & 2 \\
\hline \multirow{5}{*}{ 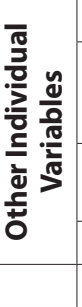 } & Emotions & 4 & & Culture & 3 \\
\hline & $\begin{array}{l}\text { Tacit knowledge/experience/ Individual } \\
\text { learning }\end{array}$ & 4 & & TOTAL & 5 \\
\hline & Forecasting ability & 2 & \multirow{3}{*}{ 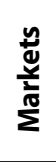 } & $\begin{array}{l}\text { Markets position, market regimes, turbulent } \\
\text { markets }\end{array}$ & 4 \\
\hline & TOTAL & 10 & & Technological change & 2 \\
\hline & & & & TOTAL & 6 \\
\hline
\end{tabular}

The table was created by the author of this article.

As the concept of bounded rationality was already defined above, it was not addressed again here. Another theme under the category of seizing, the analogical reasoning, is any type of analogy-based thinking. In other words, it is a form of analogical reasoning which refers to the analogies acknowledged to exist between two systems for the purpose of supporting the inference that there are more analogies (Goldstein, 2014).

${ }^{2} \mathrm{f}$ means frequency. In addition, the number of articles examined in Table 3 during the period 1995-2007 was 74 and the total number of frequencies was 290. The difference is that each article has 4 or 5 keywords. 
The other two concepts which emerge in this stage are emotions and tacit knowledge. Emotions are biological conditions which come into play along with neurophysiologic changes and appertain to the neural system (Ostell, 1996). In other words, emotions are the result of evaluative responses to observed stimuli that serve to catalyze behavior (Good et al., 2016). They cover the feelings, thoughts, behavioral reactions and states such as pleasure or displeasure, anxiety, stress and anger. The other concept, tacit knowledge, is the case of having knowledge and ability which nobody owns (Polanyi, 1962-1967). It is also called as the know-how. It is a type of knowledge with competitive power.

It is discerned that the research topics within the category of organization under the main category of organizational level were capabilities, organizational learning, organizational performance, organizational change, organizational identity, organizational evolution and organizational context. Moreover, it is ascertained that the dominant research topics within the category of strategic phenomena again under the main category of organizational level are competitive dynamics, strategic groups and strategic change. It is also identified that the research topics within the categories of social networks, social context, institutions and markets at the interorganizational and contextual levels in the period of 1995-2007 did not occupy a significant place in the research on cognitive foundations of strategic management

\subsubsection{Effects of Research Topics in the Period 2008-2020}

Also in the period of 2008-2020, the findings were grouped in a similar vein to the first period under the main categories of individual, organizational, interorganizational and contextual levels. Table 4 displayed the findings appertaining to this period. The effects of research topics under the category of cognition were more intensified in this period than they were in the first period. The research topics such as the managerial and organizational cognition, cognitive schemata and cognitive bias are the same as the topics of the first period. Research topics which are different in this period from those of the first period are the phenomena of entrepreneurial cognition, social cognition, leader rhetoric/language/communication, cognitive capability, creative cognition, strategic cognition and shared cognition. Entrepreneurial cognition refers to the mental structure of the entrepreneurs about the entrepreneurial activities in which they will invest
(Shepherd et al., 2007). This cognition is the knowledge structures which enable the human beings to perceive and assess the opportunities and threats in the market and making decisions about them (Goldstein, 2014). Social cognition pertains to the ways in which the human beings think of themselves and the social world and the manners in which they select, interpret, recall and use social information while reaching judgments and making decisions (Aronson et al., 2005). Another theme which comes forward in this period is the leaders' rhetoric. This rhetoric covers the leaders' ways of employing the language and communication skills.

Moreover, the phenomena such as the creative cognition, shared cognition and strategic cognition together with managers' cognitive capabilities are the topics which come to the forefront under the category of cognition. Of these concepts, the strategic cognition focuses on the connections between cognitive structures and decision processes in strategic management in terms of development and implementation of the strategy (Narayanan et al., 2011). The phenomenon of shared cognition is the cognition type which has effect on the aims and activities of the entire group and comes into being along with the combination of individuals' cognitive activities (Cannon-Bowers \& Salas, 2001).

Unlike the first period, CEO overconfidence, hubris and overoptimism came forward in this period under the category of top management/entrepreneur. These concepts can be characterized as CEO's personal features which affect his/her decision-making process as a consequence of his/her overconfidence, optimism and arrogance. It is discerned that, among the research themes to be evaluated under the category of sensing and coming to the fore in the period of 2008-2020, the phenomena which did not come forth in the first period are managerial attention and opportunity recognition. The phenomenon of managerial attention emerged in strategic management along with attention-based view (Ocasio, 1997). This view offered an explanation to the connection between structural factors inside and outside the organization and to the phenomenon of attention which was one of the cognitive features of managers. The concept of opportunity recognition which came to the fore solely in this period but not in the first period is a phenomenon which explains how firms in general and managers and employees in particular identified new opportunities which they did not know until that time (Mahnke et al., 2007). 
Table 4: Research Topics in the Period of 2008-2020

\begin{tabular}{|c|c|c|c|c|c|}
\hline \multicolumn{2}{|r|}{ Individual Level } & $\mathbf{f}^{3}$ & \multicolumn{2}{|r|}{ Organizational Level } & $\mathbf{f}$ \\
\hline \multirow{12}{*}{ : } & Managerial and Organizational Cognition & 112 & \multirow{12}{*}{ 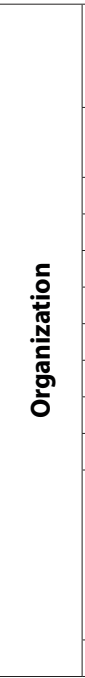 } & $\begin{array}{l}\text { Dynamic capabilities, resources, exploration- } \\
\text { exploitation, ambidexterity/innovation, } \\
\text { reconfiguration }\end{array}$ & 70 \\
\hline & $\begin{array}{l}\text { Cognitive/mental/knowledge/belief schemas, maps, } \\
\text { frames, lenses, representations, structures, process }\end{array}$ & 86 & & Organizational performance & 18 \\
\hline & Entrepreneurial cognition & 13 & & Organizational learning & 7 \\
\hline & Social cognition & 7 & & Organizational identity & 6 \\
\hline & Leader rhetoric, Language, communication & 7 & & Organizational change & 5 \\
\hline & Cognitive capability & 6 & & Organizational growth & 5 \\
\hline & Cognitive framing/ bias & 5 & & Business model & 5 \\
\hline & Creative cognition & 5 & & Corporate governance & 5 \\
\hline & Strategic cognition & 4 & & Organizational adaptation & 4 \\
\hline & Shared cognition & 4 & & Organizational attention & 4 \\
\hline & $\begin{array}{l}\text { Other cognitive factors (distributed cognitions, } \\
\text { dissonance, novelty, resources, flexibility, outcome, } \\
\text { distance, self-regulated cognition, diversity, } \\
\text { processes, breakthroughs, conflict, fit) }\end{array}$ & 20 & & $\begin{array}{l}\text { Other organizational factors (incentives, reputation, } \\
\text { context, conflict, language, information processing, } \\
\text { decline, habitat selection, turnaround, architecture, } \\
\text { design, culture, inertia, decision-making, structures, } \\
\text { behavior, evolution, memory) }\end{array}$ & 31 \\
\hline & TOTAL & 269 & & $\begin{array}{ll}\text { TOTAL } \\
\end{array}$ & 160 \\
\hline \multirow{7}{*}{ 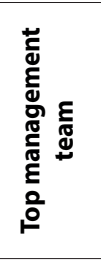 } & Entrepreneurship & 25 & \multicolumn{3}{|c|}{ Organizational Level } \\
\hline & Top management teams and CEO & 7 & \multirow{15}{*}{ 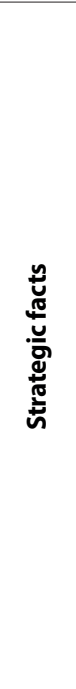 } & Behavioral strategy & 13 \\
\hline & Entrepreneurs/Founders & 6 & & Strategy as a practice & 9 \\
\hline & CEO overconfidence, hubris, overoptimism & 6 & & Competitive dynamics & 8 \\
\hline & Managerial human/social capital & 3 & & Strategy implementation & 7 \\
\hline & Strategic leadership & 2 & & & \\
\hline & TOTAL & 49 & & Strategy process & 6 \\
\hline \multirow{8}{*}{ 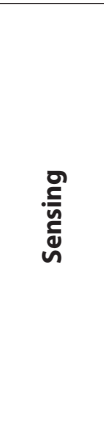 } & Managerial attention & 35 & & Strategic renewal & 6 \\
\hline & Opportunity recognition & 14 & & Strategic issue diagnosis & 3 \\
\hline & Sense-making/sensing & 10 & & Strategic groups & 3 \\
\hline & $\begin{array}{l}\text { Non-conscious forms of cognition (e.g. Intuition, } \\
\text { Heuristics) }\end{array}$ & 9 & & Competitive strategy & 3 \\
\hline & Interpretation & 7 & & Strategic entrepreneurship & 2 \\
\hline & Managerial/subjective perception & 6 & & Strategic consensus & 2 \\
\hline & Scanning/search processes & 4 & & Strategic adaptation & 2 \\
\hline & TOTAL & 85 & & $\begin{array}{l}\text { Other strategic factors (Strategic responses, } \\
\text { interventions, imitation, generic strategies, formation, } \\
\text { formulation, success, sustainability, tools, value-based } \\
\text { strategy) }\end{array}$ & 10 \\
\hline \multirow{7}{*}{ 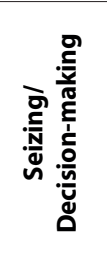 } & Managerial decision-making & 25 & & $\begin{array}{ll}\text { TOTAL } \\
\end{array}$ & 74 \\
\hline & Analogical reasoning/ problem solving & 11 & \multicolumn{3}{|c|}{ Interorganizational Level } \\
\hline & Strategic decision-making & 7 & \multirow{4}{*}{$\frac{y}{\underline{y}}$} & Social networks & 16 \\
\hline & Automatic and controlled information processing & 3 & & Sociocognitive network & 4 \\
\hline & Strategic/rational choice & 3 & & Mergers, acquisition & 1 \\
\hline & Managerial Judgment & 2 & & TOTAL & 21 \\
\hline & TOTAL & 51 & \multirow{5}{*}{ 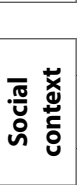 } & Contextual Level & \\
\hline \multirow{13}{*}{ 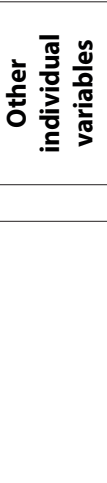 } & Emotions & 8 & & Environmental context & 8 \\
\hline & Individual differences & 6 & & Structural mechanisms & 3 \\
\hline & Motivation & 6 & & Environmental uncertainty & 2 \\
\hline & Tacit knowledge/experience/ individual learning & 6 & & TOTAL & 13 \\
\hline & Age and Educational Diversity & 3 & \multirow{4}{*}{ 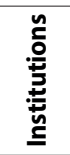 } & National and international institutions & 2 \\
\hline & TOTAL & 29 & & Institutional field (logics, change, isomorphism) & 4 \\
\hline & & & & Culture & 2 \\
\hline & & & & TOTAL & 8 \\
\hline & & & \multirow{5}{*}{ 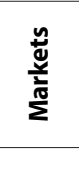 } & Technological change & 4 \\
\hline & & & & Market entry & 4 \\
\hline & & & & Industry velocity/complexity & 4 \\
\hline & & & & Market orientation & 2 \\
\hline & & & & TOTAL & 14 \\
\hline
\end{tabular}

The table was created by the author of this article.

${ }^{3} \mathrm{f}$ means frequency. In addition, the number of articles examined in Table 4 during the period 2008-2020 was 186 and the total number of frequencies was 773. The difference is that each article has 4 or 5 keywords. 
It was ascertained that a new research theme did not emerge under the category of seizing/decision-making in the period of 2008-2020 unlike the first period, however, research topics under the already existing categories were more frequently studied in this period. Particularly the managerial decision-making, analogical reasoning and strategic decision-making are among these research topics. Moreover, it is identified that the number of research studies on emotions and tacit knowledge under the category of other individual variables increased in this period. Besides, individual differences and motivation came forward as the new research topics under this category.

Upon the review of research topics under the category of organization, it is discerned that the themes of dynamic capabilities, organizational performance, organizational learning, organizational identity, organizational change, organizational growth, business model, corporate governance, organizational adaptation, organizational/transactive memory, organizational attention, organizational design, organizational culture and organizational inertia came to the fore. Behavioral strategy (Powell et al., 2011), strategy as a practice (Whittington, 2007), competitive dynamics, strategy implementation and strategy process were within the context of strategic phenomena evaluated at the organization level. Especially the studies based on the behavioral strategy are studies performed in pursuit of psychological foundations in general and cognitive foundations in particular for strategic management. The behavioral strategy combines the cognitive and social psychology with strategic management theory and practice. The behavioral strategy aims to introduce realistic assumptions about human cognition, emotions and social behaviors to the strategic management of organizations and hence to enrich the strategy theory, empirical research and real world (Powell et al., 2011).

The review of research topics under the category of social networks in this period demonstrates that both the topic titles got diversified and the research studies were focused on topics such as social networks, interorganizational networks and sociocognitive networks. As per the evaluation of categories under the main category of contextual level, it was ascertained that there was an increase also in research themes relevant to the social context, institutions and markets. It was found that the research efforts got more concentrated on environmental context and structural mechanisms under the category of social context and on techno- logical change, market entry and industry velocity/ complexity under the category of markets.

\section{Discussion}

This research study which addressed the cognitive and behavioral foundations of strategic management discipline analyzed the theoretical foundations of this research field, research orientations and the transformation of both phenomena in the periods of 1995-2007 and 2008-2020. The findings obtained from this study can be evaluated in two parts. Firstly, it was found that the different theories from economics, sociology and psychology disciplines contributed to the cognitive foundations of strategic management. It is discerned that the usage frequency of theories grew up and the types of these theories got diversified from the first period to the second period. From among these theories, 'A Behavioral Theory of the Firm' of economics lays the behavioral foundations whereas 'Social Cognitive Theory' of psychology provides the cognitive foundations of strategic management. Both theories had dominant effects on the strategic management especially in the period of 2008-2020. This situation is an indicator of the interlocked condition of both behavioral and cognitive studies in the field of strategic management. Both economics-based and psychology-based theories show that the studies orientated toward behavioral economics exist in the field of strategic management (Loewenstein, Rick \& Cohen, 2008). The mixing of economics-based and psychology-based research studies revealed the existence of a quest for research on social cognitive neuroscience (Lieberman, 2007) and neurostrategy (Laureiro-Martínez et al., 2015; Powell, 2011; Powell, 2016; Bagozzi et al., 2013). Thus, it can be asserted that a new field of neurostrategy based on neuroscience came into existence with respect to the cognitive and behavioral foundations of strategic management. This situation demonstrates also that neuroscience-based research studies which were performed in recent years with electroencephalography (EEG), positron emission tomography (PET)/computed tomography scanning (CT or CAT-scan) and functional magnetic resonance imaging (fMRI) as well as the conventional research methods and techniques (Powell, 2016) started to flourish in the research on the field of strategic management.

The effect of economics, sociology and psychology disciplines on the field of strategic management indicates that the research on the topic of cognitive foundations eclectically made progress as in the case 
of the nature of strategic management (Barca, 2017). This situation supports the richness and productivity of the field even though it creates a messy scene. It can be stated that the eclectic studies created a fortune also in terms of the use of methodological approaches in the field. Another point which is identified at the disciplinary platform is that the studies are performed in the field with sociology-based macro-level theories besides micro-level theories which are solely based on economics and psychology. This situation demonstrates that the studies on the cognitive foundations of strategic management are not supposed to be confined to a single level of analysis.

Upon the evaluation of the effects of research topics in the field of strategic management, it was found that the number of studies on the cognitive foundations of strategic management went up in the second period in comparison to the first period. Data indicated in Table 3 and Table 4 are supportive of this situation. It can be said that researches on entrepreneur, entrepreneurship, entrepreneurial cognition, top management team, and individual characteristics specific to the CEO, which had no effect in the first period, increased in the second period. This increase is due to the effort of CEO and senior management teams to understand the effects of cognitive structures and processes on strategic decisions and firm behavior. In addition, this increase is also due to the intensification of the CEO, top management team and entrepreneurship phenomenon in the cognitive-based research in the Strategic Entrepreneurship Journal, which started its publication life in 2007.

Another research topic, the effect of which grew in the second period vis-à-vis the first period, is the phenomenon of attention. This growth was linked with the research studies on the micro foundations of strategic management. Especially the researchers who endeavored to identify the cognitive phenomena covered by the sensing capability (Teece, 2007) placed the focus on attention and perception (Helfat \& Peteraf, 2015). Again, the growth in the effect of organizational phenomena such as organizational growth, business model, corporate governance, organizational adaptation and organizational attention in the second period unlike the first period demonstrates that the cognitive phenomena were still questioned in the micro foundations of macro phenomena and, so far, there was an unfinished story. The fact that the research studies with the theme of behavioral strategy were not influential in the first period whilst their influence grew in the second period indicates that the researchers endeavored to focus on this field in the second period (Foss, 2020; Powell et al., 2011). Likewise, it is discerned that the studies related to the interorganizational and contextual levels of analysis which had relatively small effect in the first period increased in number in the second period. This situation indicates that the attempts were initiated to perform the research studies on the cognitive foundations of strategic management at multiple levels of analysis and to analyze the effects of structural factors on individuals' mental activities and the effects of individuals' cognitive features on structural elements.

In addition, the findings of this research in Table 3 and Table 4 support the research first made by Walsh, (1995). Walsh (1995) revealed that the cognitive studies in the field of management are guided by the facts at the individual, group, organization and industry levels. The findings of this study also show that research on the cognitive and behavioral foundations of strategic management is driven by individual, organizational, inter-organizational and contextual phenomena. Secondly, the study by Kaplan (2011), which examines the coexistence of strategy and cognition research, did not comprehensively mention the theories that guide cognitive and behavioral foundations, but presented keywords related to cognition for 226 articles that quoted only Porac et al., (1989). Differing from the findings in Kaplan's (2011) study, the findings in this study show that, as can be seen in Table 3 and Table 4, entrepreneurship, organizational, inter-organizational and contextual-level phenomena guide the research on cognitive and behavioral foundations. Finally, this study supports the findings of the unifying framework presented in the study by Narayanan et al. (2011). Narayanan et al., (2011) found that the facts about strategic cognition should be evaluated together with environmental, organizational and individual factors. However, the authors did not provide any information about the effects of inter-organizational factors on cognitive and behavioral foundations. In this study, the findings in Table 3 and Table 4 differ from Narayanan et al., (2011) by revealing that inter-organizational phenomena also guide the studies on cognitive and behavioral foundations.

\section{Conclusion}

This research study which addressed the cognitive and behavioral foundations for the last 25 years in the field of strategic management analyzed the transformation and development patterns of the field in the periods of 1995-2007 and 2008-2020. It can be asserted 
that this research study made two contributions to the relevant literature. Firstly, the theories and research topics which guided the cognitive and behavioral foundations of strategic management were identified. Secondly, the research proposals which were likely to make contributions to the research on cognitive and behavioral foundations were made. In this regard, results of the research and prospective research proposals can be presented in six sections. First of all, it can be stated that, under 'Social Cognitive Theory', certain concepts such as self-regulatory are not sufficiently used in the research of cognitive phenomena, and these concepts have bright prospects in the behavioral strategy research (Hodgkinson \& Healey, 2011). Under 'Social Cognitive Theory', self-referential concepts such as symbolizing capability, forethought capability, vicarious capability, self-regulatory capability, self-reflective capability, self-believe and self efficacy (Bandura, 1986) can guide the way for new research on cognitive and behavioral foundations of strategic management. It was asserted that managers' decision-making processes were shaped by these self-referential phenomena (Wood \& Bandura, 1989). However, what sort of contributions these concepts would make to the cognitive and behavioral foundations of strategic management was not yet studied.

Second, it can be suggested that the contributions which were made to the cognitive foundations of strategic management by automatic (system 1, type 1) and conscious (system 2, type 2) thinking (information-processing) processes which were developed by Stanovich (2011) on the basis of Dual-Process Theory were not adequately analyzed. The findings in Table 3 and Table 4 support this situation. In the framework of these definitions, the following research question deserves to be addressed in terms of the micro foundations of strategic management: How do the firm managers have the right balance between automatic and controlled thinking in the process of renewing the organizational capabilities?

Third, the development phase of the research on the cognitive foundations of strategic management still continues. On the basis of the combination of economics and psychology disciplines, the studies on the fields such as behavioral economics, neuroeconomics, neuroscience, behavioral strategy, neurostrategy prove the existence of new pursuits. The neuroscientific studies performed recently in these fields with conventional methods and techniques show that people's verbal or written statements do not always reflect the reality.
As exhibited in Table 3 and Table 4 in the part devoted to the findings of this current research, our decisions can be guided by several sub-conscious, unconscious and non-conscious forms of cognition (e.g. intuition, heuristics) which we fail to explain consciously. Thus, as the conventional qualitative and quantitative research methods are based on human beings' verbal/written responses or decisions, making inferences solely based on behaviors without understanding the mental processes will provide us with information only on human beings' actions. As a result of this situation, the main reasons which give rise to the relevant behavior are neglected. Thus, it can be asserted that the new advancements will be made in the field along with the concurrent use of methods and research techniques in the field of neuroscience and conventional methods and techniques.

Fourth, the phenomena such as self-control, endowment effect (Thaler \& Sunstein, 2009), default effect, framing effect, availability heuristic, anchoring and processes of decision-making with intuitions, prejudices and under uncertainty (Kahneman, 2011; Kahneman, Slovic \& Tversky, 1982) can make contributions to the research on the behavioral strategy.

Fifth, what sort of contributions the research studies to be performed in light of the history discipline (Argyres et al., 2020) would make was brought up for discussion. In these discussions, the micro foundations of dynamic capabilities were addressed in the context of history as objective fact, history as interpretive rhetoric and history as imaginative future-perfect thinking (Suddaby et al., 2020). In the study by Suddaby et al., (2020), it was asserted that the capacity to manage the perceptions of the past, present and future was a cognitive capacity in support of micro foundations of the dynamic capabilities. Thus, on the basis of history discipline, the prospective research studies can make significant contributions to the cognitive aims of strategic management.

Sixth, from the findings in Table 3 and Table 4, it is seen that formal and informal institutions are not sufficiently examined. Therefore, future research can investigate the effects of formal and informal institutions in the contexts of developed and developing countries on the cognitive structures of managers and the reflection of this effect on firm behavior and performance. In addition, another finding available from Table 3 and Table 4 reveals that artificial intelligence, learning machines, internet of things, industry 4 and cyber security are not associated with managerial and 
organizational cognition research. Therefore, future research can examine the effects of these technological developments on managerial and organizational cognition and the reflection of this effect on firm behavior and performance.

Lastly, it is discerned that the research studies which guided the cognitive foundations of strategic management were performed at individual, organizational, interorganizational and contextual levels of analysis. The findings indicated in Table 3 and Table 4 show that the effects of cultural factors at the contextual level of analysis over the cognitive phenomena were insufficiently analyzed. Therefore, if the prospective studies analyze the effects of cultural factors at different country contexts over the cognitive structures of firm managers, new developments can be triggered. 


\section{References}

https://moc.aom.org/about-us/new-item3, Date of Access: 26.03.2021.

Abell, P., Felin, T., \& Foss, N. (2008). Building micro-foundations for the routines, capabilities, and performance links. Managerial and Decision Economics, 29(6), 489-502.

Acedo, F. J., Barroso, C., \& Galan, J. L. (2006). The resource-based theory: dissemination and main trends. Strategic Management Journal, 27(7), 621-636.

Adner, R., \& Helfat, C. E. (2003). Corporate effects and dynamic managerial capabilities. Strategic Management Journal, 24(10), 1011-1025.

Argyres, N. S., De Massis, A., Foss, N. J., Frattini, F., Jones, G., \& Silverman, B. S. (2020). History-informed strategy research: The promise of history and historical research methods in advancing strategy scholarship. Strategic Management Journal, 41(3), 343-368.

Aronson, E., Wilson, T., \& Akert, R. (2005). Social Psychology, New Jersey, NY: Pearson Education, Inc.

Bagozzi, R. P., Verbeke, W. J., Dietvorst, R. C., Belschak, F. D., van den Berg, W. E., \& Rietdijk, W. J. (2013). Theory of mind and empathic explanations of Machiavellianism: $A$ neuroscience perspective. Journal of Management, 39(7), 1760-1798.

Bağış, M. (2018). Dinamik yeteneklerin mikro temelleri olarak etkileşimsel yaratıcılık yaklaşımı. İ̧̧letme Araştırmaları Dergisi, 10(4), 1163-1185.

Bağış, M. (2020). A Longitudinal Analysis on the Micro-foundations of Strategic Management: Where are Micro-foundations Going? Business \& Management Studies: An International Journal, 8(2), 1310-1333.

Bağış, M., \& Hızıroğlu, M. (2018). Stratejik Yönetim'in Kaynaklara Dayalı Yaklaşımı-Ekonomik, Sosyolojik, Psikolojik Temeller. Nobel Akademik Yayıncılık Eğitim Danışmanlık Tic. Ltd. Şti..

Bağış, M., Karagüzel, E. S., Kryeziu, L., \& Ardıç, K. (2019). A Longitudinal analysis on intellectual structure of human resources management: Theoretical foundations and research trends. Mehmet Akif Ersoy Üniversitesi Iktisadi ve Idari Bilimler Fakültesi Dergisi, 6(3), 796-814.

Bandura, A. (1986). Social foundations of thought and action: $A$ social cognitive theory: Prentice-Hall, Inc.

Bandura, A. (1988). Organisational applications of social cognitive theory. Australian Journal of Management, 13(2), 275-302.

Bandura, A. (1989). Human agency in social cognitive theory. American Psychologist, 44(9), 1175-1184.

Bandura, A. (1991). Social cognitive theory of self-regulation. Organizational Behavior and Human Decision Processes, 50(2), 248-287.

Barca, M. (2017). Economic foundations of strategic management. Routledge.
Barney, J. (1991). Firm resources and sustained competitive advantage. Journal of Management, 17(1), 99-120.

Baum, J. R., \& Bird, B. J. (2010). The successful intelligence of high-growth entrepreneurs: Links to new venture growth. Organization Science, 21(2), 397-412.

Bowen, G. A. (2009). Document analysis as a qualitative research method. Qualitative Research Journal, 9(2), 27-40.

Bromiley, P. (2009). The behavioral foundations of strategic management: John Wiley \& Sons.

Cannon-Bowers, J. A., \& Salas, E. (2001). Reflections on shared cognition. Journal of Organizational Behavior: The International Journal of Industrial, Occupational and Organizational Psychology and Behavior, 22(2), 195-202.

Cyert, R. M., \& March, J. G. (1963). A behavioral theory of the firm. New Jersey: Prentice-Hall, Inc.

Çark, Ö. (2020). İşletmelerin dijital dönüşüm sürecinde "nesnelerin interneti" teknolojisinin etkisi. Turkish Studies - Economy, 15(3), 1247-1266.

Das, T., \& Teng, B. S. (2001). Strategic risk behaviour and its temporalities: between risk propensity and decision context. Journal of Management Studies, 38(4), 515-534.

De Wit, B., \& Meyer, R. (2010). Strategy: process, content, context: an international perspective: Cengage Learning EMEA.

Dyer, J. H., \& Singh, H. (1998). The relational view: Cooperative strategy and sources of interorganizational competitive advantage. Academy of Management Review, 23(4), 660-679.

Felin, T., \& Foss, N. J. (2005). Strategic organization: A field in search of micro-foundations. Strategic Organization, 3(4), 441-455.

Felin, T., Foss, N. J., Heimeriks, K. H., \& Madsen, T. L. (2012). Microfoundations of routines and capabilities: Individuals, processes, and structure. Journal of Management Studies, 49(8), 1351-1374.

Felin, T., \& Zenger, T. R. (2009). Entrepreneurs as theorists: on the origins of collective beliefs and novel strategies. Strategic Entrepreneurship Journal, 3(2), 127-146.

Fernandez-Alles, M., \& Ramos-Rodríguez, A. (2009). Intellectual structure of human resources management research: A bibliometric analysis of the journal Human Resource Management, 1985-2005. Journal of the American Society for Information Science and Technology, 60(1), 161-175.

Foss, N. J. (2020). Behavioral strategy and the COVID-19 disruption. Journal of Management, 46(8), 1322-1329.

Gavetti, G. (2005). Cognition and hierarchy: Rethinking the microfoundations of capabilities' development. Organization Science, 16(6), 599-617.

Gavetti, G., \& Rivkin, J. W. (2007). On the origin of strategy: Action and cognition over time. Organization Science, 18(3), 420-439.

Goldstein, E. B. (2014). Cognitive psychology: Connecting mind, research and everyday experience: Nelson Education. 
Good, D. J., Lyddy, C. J., Glomb, T. M., Bono, J. E., Brown, K. W., Duffy, M. K., \& Lazar, S. W. (2016). Contemplating mindfulness at work: An integrative review. Journal of Management, 42(1), 114-142.

Grant, R. M. (1996). Toward a knowledge-based theory of the firm. Strategic Management Journal, 17(S2), 109-122.

Grégoire, D. A., Corbett, A. C., \& McMullen, J. S. (2011). The cognitive perspective in entrepreneurship: An agenda for future research. Journal of Management Studies, 48(6), 1443-1477.

Gulati, R. (1999). Network location and learning: The influence of network resources and firm capabilities on alliance formation. Strategic Management Journal, 20(5), 397-420.

Gürbüz, S., \& Şahin, F. (2014). Sosyal bilimlerde araştırma yöntemleri. Ankara: Seçkin Yayıncılık.

Haleblian, J., \& Rajagopalan, N. (2005). Top Managerial Cognitions, Past Performance. And Strategic Change: A Theoretical Framework, in Gabriel Szulanski Joe Porac Yves Doz (ed.) Strategy Process (Advances in Strategic Management, Volume 22). Emerald Group Publishing Limited, 63-91.

Hart, S. L. (1995). A natural-resource-based view of the firm. Academy of Management Review, 20(4), 986-1014.

Helfat, C. E., \& Peteraf, M. A. (2015). Managerial cognitive capabilities and the microfoundations of dynamic capabilities. Strategic Management Journal, 36(6), 831-850.

Hmieleski, K. M., \& Baron, R. A. (2008). When does entrepreneurial self-efficacy enhance versus reduce firm performance? Strategic Entrepreneurship Journal, 2(1), 57-72.

Hodgkinson, G. P., \& Healey, M. P. (2011). Psychological foundations of dynamic capabilities: reflexion and reflection in strategic management. Strategic Management Journal, 32(13), 1500-1516.

Hodgson, G. M. (2012). The mirage of microfoundations. Journal of Management Studies, 49(8), 1389-1394.

Jemison, D. B. (1981). The importance of an integrative approach to strategic management research. Academy of Management Review, 6(4), 601-608.

Kahneman, D. (2011). Thinking, fast and slow: Macmillan.

Kahneman, D., Slovic, S. P., \& Tversky, A. (1982). Judgment under uncertainty: Heuristics and biases: Cambridge University Press.

Kahneman, D., \&Tversky, A. (1979). Prospect theory: An analysis of decision under risk. Econometrica: Journal of the Econometric Society, 47(2), 263-291.

Kaplan, S. (2011). Research in cognition and strategy: Reflections on two decades of progress and a look to the future. Journal of Management Studies, 48(3), 665-695.

Kiss, A. N., \& Barr, P. S. (2015). New venture strategic adaptation: The interplay of belief structures and industry context. Strategic Management Journal, 36(8), 1245-1263.

Laureiro-Martínez, D., Venkatraman, V., Cappa, S., Zollo, M., \& Brusoni, S. (2015). Cognitive neurosciences and strategic management: Challenges and opportunities in tying the knot. Advances in Strategic Management (Cognition and Strategy), 32, 351-370.
Lavie, D. (2006). The competitive advantage of interconnected firms: An extension of the resource-based view. Academy of Management Review, 31(3), 638-658.

Lieberman, M.D. (2007). Social cognitive neuroscience: a review of core processes. Annual Review Psychology, 58, 259-289.

Lippman, S. A., \& Rumelt, R. P. (2003). The payments perspective: micro-foundations of resource analysis. Strategic Management Journal, 24(10), 903-927.

Loewenstein, G., Rick, S., \& Cohen, J. D. (2008). Neuroeconomics. Annual Review Psychology, 59, 647-672.

Mahnke, V., Venzin, M., \& Zahra, S. A. (2007). Governing entrepreneurial opportunity recognition in MNEs: Aligning interests and cognition under uncertainty. Journal of Management Studies, 44(7), 1278-1298.

March, J. G. (1994). Primer on decision making: How decisions happen. Simon and Schuster.

Miles, M. B., \& Huberman, A. M. (1994). Qualitative data analysis: An expanded sourcebook. London, New Delhi: Sage Publications.

Mintzberg, H. (1990). Strategy formation: Schools of thought. Perspectives on Strategic Management, 1968, 105-235.

Narayanan, V. K., Zane, L. J., \& Kemmerer, B. (2011). The cognitive perspective in strategy: An integrative review. Journal of Management, 37(1), 305-351.

Ocasio, W. (1997). Towards an attention based view of the firm. Strategic Management Journal, 18(S1), 187-206.

Ocasio, W. (2011). Attention to attention. Organization Science, 22(5), 1286-1296.

Ostell, A. (1996). Managing dysfunctional emotions in organizations. Journal of Management Studies, 33(4), 525-557.

Peng, M. W. (2002). Towards an institution-based view of business strategy. Asia Pacific Journal of Management, 19(2-3), 251-267.

Peng, M. W., Sun, S. L., Pinkham, B., \& Chen, H. (2009). The institution-based view as a third leg for a strategy tripod. Academy of Management Perspectives, 23(3), 63-81.

Peteraf, M. A. (1993). The cornerstones of competitive advantage: a resource-based view. Strategic Management Journal, 14(3), 179-191.

Polanyi, M. (1962). Tacit knowing: Its bearing on some problems of philosophy. Reviews of Modern Physics, 34(4), 601-616.

Polanyi, M. (1967). The tacit dimension. Garden City, NY: Anchor.

Porac, J. F., Thomas, H., \& Baden-Fuller, C. (1989). Competitive groups as cognitive communities: The case of Scottish knitwear manufacturers. Journal of Management Studies, 26(4), 397-416.

Porter, M. E. (1980). Competitive startegy: Technigues for analyzing industries and competitors. New York: Free Press.

Porter, M. E. (1981). The contributions of industrial organization to strategic management. Academy of Management Review, 6(4), 609-620.

Powell, T. C. (2011). Neurostrategy. Strategic Management Journal, 32(13), 1484-1499. 
Powell, T. C. (2016). Neurostrategy. In D. J. Teece \& M. Augier (Eds.), The Palgrave Encyclopedia of Strategic Management. London: Palgrave Macmillan.

Powell, T. C., Lovallo, D., \& Fox, C. R. (2011). Behavioral strategy. Strategic Management Journal, 32(13), 1369-1386.

Ramos-Rodríguez, A. R., \& Ruíz-Navarro, J. (2004). Changes in the intellectual structure of strategic management research: A bibliometric study of the Strategic Management Journal, 1980-2000. Strategic Management Journal, 25(10), 981-1004.

Seijts, G. H., Latham, G. P., Tasa, K., \& Latham, B. W. (2004). Goal setting and goal orientation: An integration of two different yet related literatures. Academy of Management Journal, 47(2), 227-239.

Shalley, C. E., \& Perry-Smith, J. E. (2008). The emergence of team creative cognition: the role of diverse outside ties, sociocognitive network centrality, and team evolution. Strategic Entrepreneurship Journal, 2(1), 23-41.

Shepherd, D. A., McMullen, J. S., \& Jennings, P. D. (2007). The formation of opportunity beliefs: Overcoming ignorance and reducing doubt. Strategic Entrepreneurship Journal, 1(1-2), 75-95.

Simon, H. A. (1947). Administrative behavior. A study of decision-making processes in administrative organization (Fourth Edition): The Free Press, New York.

Stanovich, K. (2011). Rationality and the reflective mind: Oxford University Press.

Suddaby, R., Coraiola, D., Harvey, C., \& Foster, W. (2020). History and the micro-foundations of dynamic capabilities. Strategic Management Journal, 41(3), 530-556.

Takemura, K. (2014). Behavioral decision theory. Psychological and mathematical descriptions of human choice behavior, Springer Japan.

Teece, D. J. (2007). Explicating dynamic capabilities: the nature and microfoundations of (sustainable) enterprise performance. Strategic Management Journal, 28(13), 1319-1350.
Teece, D. J., Pisano, G., \& Shuen, A. (1997). Dynamic capabilities and strategic management. Strategic Management Journal, 18(7), 509-533.

Thaler, R. H., \& Sunstein, C. R. (2009). Nudge: Improving decisions about health, wealth, and happiness. Penguin.

Uygur, U., \& Kim, S. M. (2016). Evolution of entrepreneurial judgment with venture-specific experience. Strategic Entrepreneurship Journal, 10(2), 169-193.

Üsdiken, B., \& Wasti, S. A. (2002). Türkiyesde akademik bir inceleme alanı olarak personel veya» insan kaynakları» yönetimi, 1972-1999. Amme İdaresi Dergisi, 35(3), 1-37.

Walsh, J. P. (1995). Managerial and organizational cognition: Notes from a trip down memory lane. Organization Science, 6(3), 280-321.

Weick, K. E. (1995). Sensemaking in organizations. Sage Publications.

Wernerfelt, B. (1984). A resource-based view of the firm. Strategic Management Journal, 5(2), 171-180.

Whittington, R. (1996). Strategy as practice. Long Range Planning, 29(5), 731-735.

Whittington, R. (2007). Strategy practice and strategy process: family differences and the sociological eye. Organization Studies, 28(10), 1575-1586.

Williamson, O. E. (1999). Strategy research: governance and competence perspectives. Strategic Management Journal, 20(12), 1087-1108.

Winter, S. G. (2012). Purpose and progress in the theory of strategy: Comments on Gavetti. Organization Science, 23(1), 288-297.

Wood, R., \& Bandura, A. (1989). Social cognitive theory of organizational management. Academy of Management Review, 14(3), 361-384.

Zupic, I., \& Čater, T. (2014). Bibliometric methods in management and organization. Organizational Research Methods, 18(3), 429-472. 